
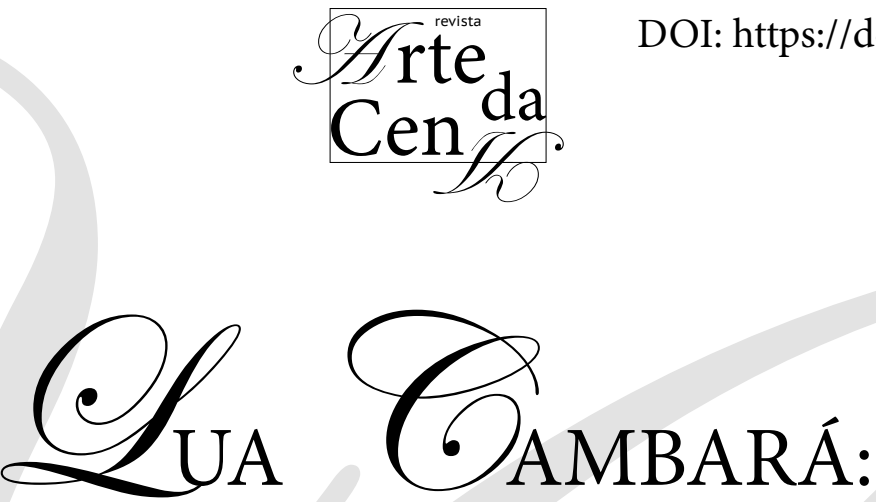

\title{
UM EXERCÍCIO POÉTICO DE CRIAÇÃO CÊNICA
}

\author{
"Lua Cambará: A Poetic Exercise of Scientific Creation."
}

Inácia Rita Maria Larissa Barros de Santana*

Programa de Pós-Graduação em Artes da Cena

Universidade Estadual de Campinas

RESUMO: Este artigo trata de uma investigação em processo sobre a construção da personagem Lua Cambará. O contexto do conto Lua Cambará, de Ronaldo Correia Brito, surge como material para a composição de cenas, em que a personagem central, Lua Cambará, ainda em latência e desejo, vem sendo esboçada a partir da noção de arquétipo em Jung; compreendendo arquétipo enquanto estímulo imagético e de ação para a criação cênica, de modo a utilizar estímulos extraídos do próprio conto para a criação. A partir de três exercícios: laboratório, oficina e passeio, como pontapé inicial, algumas reflexões estão surgindo sobre a personagem, cujas camadas estão sendo compreendidas como um aspecto tríplice que encarna qualidades dos arquétipos de Oxum, Yansã e Nanã. Este artigo, portanto é um primeiro exercício de análise sobre a personagem Lua Cambará e o modo de criação que situa esta numa abordagem arquetípica.

Palavras-chave: Literatura brasileira, Lua Cambará, arquétipo, criação cênica, processo criativo.

ABSTRACT: This article deals with an investigation in process on the construction of the character Lua Cambará. The context of the Lua Cambará story by Ronaldo Correia Brito appears as material for the composition of scenes, in which the central character, Lua Cambará, still in latency and desire, has been sketched from the notion of archetype in Jung; Understanding archetype as an imaginary and action stimulus for the scenic creation, in order to use stimuli extracted from the own tale for the creation. From three exercises: laboratory, workshop and walk, as a kick-start, some reflections are arising on the character, whose layers are being understood as a triple aspect that embodies qualities of the archetypes of Oxum, Yansan and Nanã. This article, therefore, is a first exercise of analysis on the character Lua Cambará and the mode of creation that places this in an archetypal approach.

KEYWORDS: Brazilian Literature, Lua Cambará, Archetype, Scenic creation, creative process.

Inácia Rita Maria Larissa Barros de Santana - Lua Cambará: um exercício poético de criação cênica. Arte da Cena, Goiânia, v. 3, n. 1, p. 108-127, Jan-jun/2017, 
Lua Cambará, o mito do corpo seco.

Lua Cambará é um dos contos do livro intitulado Faca, do escritor cearence Ronaldo Correia Brito. O livro foi escrito no estilo regionalista, repleto de histórias cortantes, como sugere o próprio título, de um sertão remoto, árido, escasso, em que as personagens procuram romper com as situações de aprisionamento, seja através da morte, do assassinato ou da fuga. Ronaldo Correia Brito difere no estilo, pois ao invés de trazer o sertanejo no papel do herói, como é característico do regionalismo brasileiro, o autor traz Irinéia, Delmira, Aldenora Morais, Francisca Justino, Inácia Leandro, Cícera Candóia, Lua Cambará, entre outras como protagonistas, sendo que esta última com traços que lembram as heroínas trágicas, um dos primeiros contos regionalistas em que aparece como protagonista uma personagem feminina.

Acerca do livro Faca, a pesquisadora Nathalia Perry Clark (2011) faz uma análise literária sobre a representação do feminino nos contos de Ronaldo Correia Brito. Ela percebe em Lua Cambará elementos transgressores e entrevista ao autor sobre suas motivações e inspirações para a personagem, Ronaldo Correia responde:

Eu escutei essa história contada inúmeras vezes por meu pai. É uma história da mitologia sertaneja. É o mito do corpo seco, história de uma personagem escravocrata do sertão dos Inhamuns. Não posso dizer seu nome... é uma história que certamente se mistura à mitologia universal. Era uma escravocrata cruel, perversa, e que contam que quando foi levada para o enterro de seu corpo, aparecem dois diabos, demônios montados à cavalo e pedem para ajudar a transportar a morta e desaparecem com ela. Então, as pessoas assustadas enterram no lugar da morta, um tronco de madeira. Então, na verdade, são mitos arcaíssimos, que são incorporados à mitologia local. A alma penada de Lua Cambará começa a ficar aparecendo aos tropeiros que se arranchavam debaixo de árvores, às pessoas que à noite estão de viagem. Eu começo o conto dizendo 'meu pai jurou que viu', é muito forte, se meu pai jurou que viu, então não há o que duvidar, mesmo as pessoas dizendo que ela é mal assombrada. O mito existe e Lua Cambará existe, e me persegue até hoje. Tanto que já virou ópera-balé, já virou disco, dois filmes, acabou de ser encenada, e é tão forte, tão real, tão palpável. (CLARK, 2011, p.195)

Nathalia Clark $^{1}$ aponta que a personagem real que deu origem ao conto, possa ter existido por volta do final do século XIX, permanecendo no imaginário popular do sertão dos Inhamuns, no Ceará, até que sua história contada oralmente nos alpendres das casas fosse mais tarde transcrita por Ronaldo Correia Brito e sua obra ficcional inspirasse composições artísticas, ganhando os palcos e telas do cinema brasileiro. Visto que a personagem surge de uma referência real, que ao ser mitificada no sertão dos inhamuns, passa a servir de fonte principal para a composição de materiais expressivos, sejam estes de natureza coreográfica, dramatúrgica, performativa, alguns trabalhos foram desenvolvidos nesse sentido,

Inácia Rita Maria Larissa Barros de Santana - Lua Cambará: um exercício poético de criação cênica. 


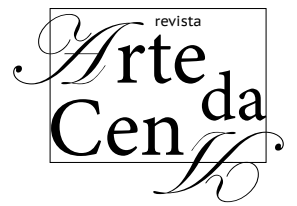

como por exemplo, o espetáculo de ópera-balé Lua Cambará, com direção geral de Cecília Brenann e o filme Lua Cambará de Rosenberg Cariry, com Dira Paes no papel de Lua, mas desde 1977 que o conto vem servindo de alento criativo para diversos trabalhos na área das artes.

Em todo o Brasil há histórias semelhantes que viraram lendas, tanto no Nordeste como no Norte, Centro-oeste e Sudeste. Algumas dão o nome dos defuntos e lugares onde viveram e como foram enterrados com tantos detalhes que o relato de tão crível beira a realidade.

O corpo seco é assim um mito em que pessoas muito perversas em vida tinham seus corpos rejeitados pela terra ao serem enterrados. Eram como que cuspidos do túmulo e por mais que tentassem mantê-los, mesmo amarrados eles teimavam em sair, como se esses corpos não tivessem completado a passagem e alguma forma de vida animasse as faces descarnadas. Acreditando-se que se tornavam mortos-vivos que esgueiravam na sombra das árvores, nas estradas escuras ou à margem de rios, pessoas desavisadas para sugar-lhes o sangue e assim escaparem do inferno. Caso não saciassem sua fome, viravam troncos retorcidos que podiam ser facilmente confundidos com troncos de árvores secos. Na maioria das lendas, os corpos-secos eram pessoas que haviam maltratado os pais, principalmente a mãe e que por isso, a terra mãe, rejeitava ter em seu ventre semente tão podre.

No caso de Lua Cambará, ela é gerada por um estupro cometido pelo coronel Pedro Franscelino do Cambará, sua mãe morre de fome e a menina é encontrada pelo capataz da fazenda mamando leite-sangue no seio da negra Maria já morta. O capataz leva a criança e apresenta ao coronel, que "reconhece a encomenda, mas não manda batizar” a bastarda mestiça. É criada sem amor, aprendendo a espancar um negro todos os dias para aliviar seus dissabores. Lua Cambará é qualquer coisa, menos politicamente correta, seus crimes não alcançam a mãe, que não chega a conhecer, nem o pai, cuja presença só impõe medo, mas o seu próprio sangue escravo e a condição de mulher. No lugar onde a morta deveria ser enterrada, os escravos enterram um tronco de árvore seco, o que dá origem ao mito do corpo seco.

No contexto do conto Lua Cambará, cabe uma metáfora: o corpo-seco como corpo- desassossego, a assombração como o próprio desejo em si, a procura, a instabilidade, o desassossego, um corpo que quer preencher-se de algo, nutrir-se de tudo.

O mote que deu origem ao mito de Lua Cambará no imaginário do povo, no sertão dos Inhamuns, permanece vivo de alguma forma, 
uma espécie de força subversora ligada aos mitos primais que ele faz ressurgir acendendo uma relação com temas recuperados das mitologias pela literatura universal, como os seres fantásticos, misteriosos e sanguinários, por exemplo, as sereias, as bruxas, os fantasmas.

Sobre a força dos mitos, Mircea Eliade faz a seguinte constatação:

O mito define-se pela sua forma de ser: não se deixa abarcar enquanto mito, a não ser na medida em que revela que qualquer coisa se manifestou plenamente, sendo esta manifestação, por sua vez, criadora e exemplar, já que também, na verdade, funda uma estrutura, do real mais que um comportamento humano. Um mito narra sempre que qualquer coisa se passou realmente, que um acontecimento teve lugar no sentido estrito da palavra quer se trate da criação do Mundo, da mais insignificante espécie animal ou vegetal ou de uma instituição. (ELIADE, 1989, p.10)

É curioso pensar nesse conto como um mito, ou a transcrição de um mito, em conformidade com a configuração como os mitos normalmente são difundidos. O que traz certo desconforto, porque não se sabe como ele foi contado a primeira vez, por quem, de que jeito, em quais circunstâncias. Coisa que não aconteceria caso se tratasse de um romance inédito à época de sua publicação.

Ao compilar relados ouvidos, vividos e imaginados, Ronaldo Correia Brito cria uma áurea em torno da personagem que torna complicado definir com precisão a sua natureza. Mas talvez daí advenha seu mistério, uma possível fricção entre vida e imaginário que traça no sobrenatural a sua permanência no tempo.

\section{0 aspecto tríplice em Lua Cambará}

O mito brasileiro de Lua Cambará acorda aspectos de repercussão muito antigos em que o elemento cósmico da lua é compreendido como emblema mítico de representação do feminino. A personagem encarna no seu ciclo de alma penada a instabilidade lunar, não só a face luminosa como a força arrebatadora da sombra.

O conto se inicia nos "três dias em que a lua morre", como se a lua nova evocasse a assombração do seu esconderijo. A lua aqui é compreendida como uma personagem dessa narrativa, pois a sua aparição/ausência, de certa forma, conduz os acontecimentos.

"A Lua que fia o Tempo, é ela que tece as existências humanas, e as deusas do destino são as Fiandeiras". (ELIADE, 1989, p.178). Possivelmente não foi por acaso, que o autor tece sua narrativa de modo a conduzir o leitor a encontrar um sentido lunar na própria estrutura em que foi escrito. $\mathrm{O}$ título do conto, o nome da personagem, as transições da personagem e o modo de narrar podem

Inácia Rita Maria Larissa Barros de Santana - Lua Cambará: um exercício poético de criação cênica. 
ser pistas de uma estrutura cíclica em que Lua Cambará apresenta três facetas muito intrigantes do seu temperamento sem deixar de ser a alma penada que passa a vagar.

Adam Mclean (1998) nos relata que as religiões matriarcais antigas tinham um culto muito difundido nas comunidades agrícolas à Deusa Tríplice a qual sintetizava o ciclo lunar e a sua influência na natureza e nos corpos femininos, no segredo da geração e morte da vida. Com a passagem das luas vinha a mudanças das estações, a germinação dos grãos, a colheita, novamente o plantio, a concepção e o nascimento de crianças. Esse culto agrário com o passar dos tempos foi perdendo importância, uma vez que as sociedades foram obtendo seu sustento de outras formas e também, cedendo lugar a cultos patriarcais devido a interesses que visavam o controle. Daí se inicia um movimento que futuramente daria origem ao pensamento dualista nas diversas sociedades humanas.

Sobre as polaridades do aspecto lunar da Deusa tríplice, Adam Mclean nos diz:

O feminino, contudo, é capaz de unir os opostos. Sua imagem cósmica é a Lua, com sua fase sombria de Lua Nova, sua fase luminosa de Lua Cheia e seus crescentes e minguantes intermediários. Ela não é constante; em vez disso, move-se num ciclo. Os deuses masculinos, identificados com a luz do Sol, não poderiam passar por um tal ciclo; suas mitologias eram forçadas a ser dualistas _ os "bons" deuses celestes e os "maus" deuses do sombrio "mundo inferior" . A deusa tríplice, por outro lado, traz em si todas as polaridades. Encontramo-la numa variedade de disfarces, e, como é mutável, ela desafia o nosso pensamento unidimensional com contradições e aparentes inconsistências. Ela muda de forma a cada volta do seu ciclo e o nosso pensamento, para compreendê-la, tem de se ajustar à mudança. (MCLEAN, 1998, p. 14).

Na Deusa Tríplice coexistem luz, sombra, penumbra, assim também em Lua Cambará, no sentido em que as polaridades do seu comportamento coexistem e se interpenetram no estado etéreo. Nessa perspectiva, talvez haja em Lua Cambará alguma reminiscência da antiga Deusa Tríplice virgem-mãe-anciã em que o trajeto da personagem no conto une as qualidades da moça, os predicados da guerreira, o lado sombrio da anciã, evocando a antiga deusa, mas compreendida aqui como luz-penumbra-sombra ou moça-guerreira-anciã. A fim de entender esses momentos, delimito trechos em que é possível observar mais claramente as mudanças de comportamento. A personagem transita por estados, os quais são percebidos aqui na forma de um aspecto tríplice, em que acordo uma relação aproximada com as deusas de matrizes afro brasileiras, mais precisamente, Oxum, Yansã, Nanã, correspondendo as facetas da moça-guerreira-ançiã, em que Lua Cambará toca os arquétipos dessas deusas e as suas mitologias em algumas passagens do conto.

Inácia Rita Maria Larissa Barros de Santana - Lua Cambará: um exercício poético de criação cênica. 
É preciso esclarecer que essa escolha não é aleatória. Poderia acordar uma relação com outros arquétipos como, por exemplo, Perséfone, Deméter, Hécate, cujos mitos figuram na prateleira dos escritos tidos como clássicos e representativos da cultura ocidental como um todo. Ou então partir para outro paralelo e escolher trabalhar a partir dos arquétipos hindus de Lakshimi, Durga, Kali, os quais são aceitos como aspectos complementares de uma só deusa. Mas resolvi aproximar com a cultura brasileira e com arquétipos que estão vivos nas manifestações religiosas e populares, tanto na dramaticidade e plasticidade das danças de terreiro, que são representações dos mitos, como nas festas de rua, nos blocos de afoxé, ou maracatu, que são apadrinhados e dedicados para algum orixá.

Seguindo, há três momentos, pelo menos, em que essa aproximação com os mitos de Oxum, Yansã é Nanã é possível.

Lua Cambará aparece como uma furiosa e vingativa assassina, cuja mão não fraqueja nem se retém. Nesta passagem, após a morte do pai, o coronel Pedro Francelino do Cambará, seus parentes não a reconhecem como legítima herdeira, devido ela ser mestiça e bastarda, por ter "gênio ruim e raça de branco". Isso desencadeia tamanha fúria que ela avança sobre a garganta dos parentes, sangrando até o último:
Ele vai querer cortar sua cabeça, tão logo eu feche os olhos. És o filho homem que não tive. Prova a coragem que tens defendendo o que é teu. (...) Ouviu-se um ruído estranho como das profundezas da terra se abrindo. (...) E viram Lua Cambará se erguer no suspiro de morte do pai, se alçando em filha herdeira, de punhal na cintura. (BRITO, 2003, p.148-149).

Nesta ocasião Lua encarna a guerreira, age com a força dos animais ferozes que atacam diante da ameaça de vida, ou no instante do bote à presa. Em um dos mitos de Yansã, compilado por Reginaldo Prandi (2001) em seu livro, Mitologia dos Orixás, encontramos na narrativa a descrição do momento em que Yansã se transforma em búfalo após ser ridicularizada pelas outras esposas de Ogum: "Ela vestiu a pele e esperou que as mulheres retornassem/ E então saiu bufando, dando chifradas em todas, abrindo-lhes a barriga." (PRANDI, 2001, p.298-299). As personagens agem de modo similar no conto e no mito, uma espécie de coragem mista de frieza no ato sanguinário.

Seguindo com a narrativa do conto, após esse momento, Lua Cambará tem urgência em lavar-se do sangue alheio. Então, vai se recompor à luz da lua, vai banhar-se nua nas águas turvas de um açude. Os elementos da natureza adquirem função na narrativa, no caso a água e a lua, juntamente atuam como apaziguadoras, Lua encontra acalanto, mas também é através desses 
elementos que temos revelada a sua sensualidade. Espreitada despida, ela se torna objeto de desejo e encantamento a quem olhar, pois sem a pele de couro que Lua veste, tal como fosse um vaqueiro, a moça aparece.

Seu vulto já montava cavalo em desembestada corrida, precisava molhar-se em águas, os confrangimentos da alma eram muitos. Que beleza devia ser aquele corpo! (...) Protegendo os peitos molhados dos olhares atrevidos, não permitia que espreitassem seu banho, sua nudez entre aguapés e babugens. Banhara-se em águas escuras de açude. Tentava lavar o sangue, acalmar-se dos fatos. (BRITO, 2003, p. 149-150).

Lua encontra-se com Oxum, quando a sua beleza, feminilidade e sensualidade são reveladas pela água, elemento primordial de domínio de Oxum, que lhe representa, mas também personifica. Oxum é a própria água, lânguida, serena, tanto quanto Yansã, representada e personificada pelo fogo e pelo raio, simbolicamente no domínio das emoções tempestivas, é o próprio raio que arrebata e destrói. Na tentativa de acalmar-se Lua age como os camaleões que assumem a cor do ambiente, procurando identificar-se com a água.

O autor vai acrescentando camadas à personagem. Lua apaixona-se por João Índio, um dos seus cabras de confiança. A hostilidade com que este recusa seu sentimento faz ela assumir um aspecto enigmático, assustador, para aqueles que se deparam com sua figura, sua amargura à leva a ruína.

A secura penetrara as entranhas de todos os seres vivos. Lua, vagando feito uma sonâmbula, magoava-se com a recusa ao seu precário amor. (...) Ardia em rancores. (...) Ela precipitou-se correndo, no emaranhado de espinhos e galhos secos da caatinga, urrando feito animal ferido, os cabelos enganchando-se nas unhas de gato e gitiranas, perdendo a sanidade e a beleza da juventude no assomo de loucura (BRITO, 2003, p.154-155).

Diante da impossibilidade de ter o seu sentimento retribuído, ela ordena seu capataz Idenfonzo Roldão a sangrar Irene, esposa de João Índio, como se faz com as cabras em dia de sábado. Porém, no instante da morte, Irene se vale da força profética da maldição, amaldiçoando Lua a vagar eternamente e a não ser aceita nem no céu, nem na terra, nem no inferno. É nas agonias da morte que Lua atua o mistério regido por Nanã, divindade Yorubá relacionada às profundas forças que atuam nos ciclos de vida e morte e no cumprimento do destino:

Ninguém viu e estavam ali, aparecidos do éter. Eram dois negros imensos, vestindo ternos brancos. Os olhos, quatro brasas vivas. Davam terror e desejo de entrega. Traziam baralhos nas mãos, sebentos de uso, adquiridos de ciganos corruptos, gastos de apostar almas. E jogaram noite afora, indiferentes à agonizante, rouca de tanto gritar para um abismo sem eco. Seu destino estava selado, das maldições não se foge, um dia a porta desaba. E os negros bem assentados em cadeiras de espaldar alto, sem uma palavra jogavam e, no baralho, só apareciam duas cartas por castigo, um morto e um enforcado. Lua arrancou da garganta

Inácia Rita Maria Larissa Barros de Santana - Lua Cambará: um exercício poético de criação cênica. 


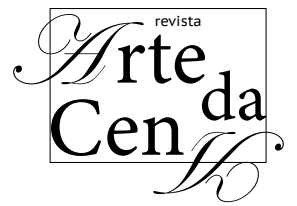

o grito que era da mãe, extraído de suas entranhas quando bebeu o leite-sangue dos seus peitos. (...) Com esse grito vagido, Lua se despediu desse mundo. (BRITO, 2003, p.164-165)

O tempo da narrativa é alinear, de modo que o autor traz a alma penada concomitantemente às passagens que Lua atravessa em vida. Há uma sobreposição de momentos que se cruzam e fazem a trama. Como assombração, Lua se encontra em trânsito, ela é uma só, mas é também três, e é também entre uma e outra, num fluxo ininterrupto. As facetas da moça-guerreira-anciã permeiam o comportamento de Lua, ora encarnando as qualidades de Yansã, de Oxum e também encenando o mistério de Nanã, como uma assombração que vaga ela evoca imagens arquetípicas universais.

\section{Implicações da pesquisa em Artes: processo criativo como gerador para a produção do conhecimento}

$\mathrm{Na}$ pesquisa em artes e consequentemente na produção de obras artísticas, o sujeito pesquisador/atuante e o campo a ser conhecido se mesclam em um único fim: "ação humana para a criação e produção de conhecimentos e sentidos" (BOLOGNESI, 2014, p.150).

Nas artes, o conhecimento se dá como prática, esta alimenta a reflexão, a análise e a produção de conhecimento. Este seria um modo de produção que foge ao encaixotamento formal, que por sua vez, não cabe às artes tais categorias tão restritivas. Acerca da pesquisa em artes, Victoria Pérez Royo, salienta que

O objeto de estudo é completamente singular - tanto que o pesquisador, para trabalhar com ele, teve que inventar uma nova linguagem, uma nova maneira de fazer as coisas e um novo procedimento ( ou teve que reformular e rearticular aqueles que conhecia antes). (ROYO, 2015, p.545-546).

Ao delimitar o conto Lua Cambará, como material para a criação de uma personagem, proponho embarcar numa pesquisa que se dá em experiência, por tentativa e erro que desemboca em pesquisa e suscita a investigação criativa e o diálogo com outras áreas do saber como a dramaturgia, a filosofia, e a psicologia. Construir as facetas da personagem e as transições entre elas se constitui um trabalho complexo, porém instigante ao lidar com seu aspecto tríplice e a sua condição de trânsito. Esse desejo me mobiliza a uma abordagem arquetípica como exercício poético de criação.

Jolande Jacobi (1990), em seu livro, Complexo, arquétipo, símbolo na psicologia de C.J. Jung, apresenta o arquétipo como um componente da psique humana que se mantém em fluxo, é assim que ele vai se atualizando. Na compreensão da autora sobre as ideias de Jung, o arquétipo é uma força que atua tanto no sentido das imagens e

Inácia Rita Maria Larissa Barros de Santana - Lua Cambará: um exercício poético de criação cênica. 
das ideias, como no sentido do impulso e instinto, como possibilidades latentes, que se atualizam quando a forma é apresentada ao consciente. Se o arquétipo é uma via de mão dupla capaz de mobilizar instinto e imaginação, então ele pode servir ao trabalho de atriz enquanto dispositivo para a criação. Dessa maneira, conjecturo a possibilidade de usar esse elemento para acordar estímulo imagético e ação cênica.

Quando Jacobi, fala que o arquétipo se mantém em fluxo, isso me faz pensar sobre uma atribuição insistentemente perseguida nos treinamentos para atores, que é a capacidade de gerar fluxo, uma das mais complexas qualidades do estado cênico.

Cabe esclarecer qual noção de fluxo é adotada aqui, nesse sentido, acredito que as pesquisas de Mihaly Cziksentmihaly (1999) publicadas sob o título A descoberta do fluxo: a psicologia do envolvimento com a vida cotidiana esclarece o que seria uma atividade que gera fluxo:

A metáfora do fluxo foi utilizada por muitas pessoas para descrever a sensação de ação sem esforço experimentada em momentos que se destacam como os melhores de suas vidas. Atletas se referem a eles como atingir o auge, místicos religiosos como estar em êxtase, artistas e músicos como enlevo artístico. (...) O fluxo tende a ocorrer quando as habilidades de uma pessoa estão totalmente envolvidas em superar um desafio que está no limiar de sua capacidade de controle. Experiências ótimas geralmente envolvem um fino equilíbrio entre capacidade do indivíduo de agir e as oportunidades disponíveis para a ação. (CZIKSENTMIHALY, 1999, p.36-37)

Algo espontâneo, sem bloqueios à ação e que acontece livremente, de modo que o indivíduo encontra-se tão absorvido pela tarefa que as distrações externas não interessam, esquecendo o que se passa em volta, simplesmente flui. Para tanto é preciso ter como elemento de trabalho a percepção de latências sutis, de algo que pode vir a ser, o devir, no instante mesmo que acontece. Assim, “a cena não se dá em, mas entre. (...) A famigerada presença do ator, longe de ser uma forma de fluidos, corresponde a sua habilidade de gerar e habitar os entre lugares da presença” (FABIÃO, p.323, 2010).

Nesse sentido, a personagem ficcional é interessante pelas fronteiras a que se pode chegar, pelo seu brilho inventivo emprestado pelo autor. Pois na medida em que reúne os artifícios da moça, guerreira e anciã, ao trabalhar com polaridades aparentemente contrárias, estabelece um desafio de fluxo.

A aplicação do arquétipo tríplice da moça-guerreira-anciã, como meio de abordagem e composição de materiais expressivos vem se constituindo por meio da leitura dos mitos de Oxum, Yansã e Nanã aliada à pesquisa iconográ-

Inácia Rita Maria Larissa Barros de Santana - Lua Cambará: um exercício poético de criação cênica. 


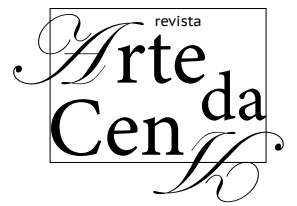

fica com enfoque no aspecto estético. A leitura do conto Lua cambará é assim vista a partir de uma perspectiva mitológica, em que o estudo dos arquétipos encarnados pela personagem se transformam em elementos utilizados como estímulo imagético e para a ação cênica.

Em busca de um norte metodológico para ancorar essa criação, me amparo na Teoria da Formatividade de Luigi Pareyson, estudo pautado no campo da estética, no ramo da filosofia. A teoria da formatividade de Luigui Pareyson (Napoli, 2008) almeja ir além dos dualismos motivados de um lado, pelas concepções formalistas, focadas na materialidade da obra artística, de outro, as conteudistas, que situam a arte como uma facilitadora de sentidos profundos externos ao produto mesmo da arte. Pareyson justapõe seu conceito de forma ao de Aristóteles nos seus estudos de biologia, assim forma para ele é análogo a organismo em Aristóteles, ou seja "um ser vivo dotado de uma finalidade própria”. Equivale expor que o feito artístico tem códigos internos próprios, singularidade e é irrepetível.

Nessa corrente filosófica, a obra artística não é concebida à priori. $\mathrm{O}$ modo de fazer vai sendo inventado na medida em que a obra mesma vai sendo feita. Trata-se de um modo de operar processual, em que o artista dispõe da capacidade de ouvir as necessidades da poética interna da obra a qual pretende desenvolver e vai dando-lhe cabimento, procurando desenvolver um diálogo entre aquilo que o artista concebe em sua mente e o que obra vai suscitando.

Nessa perspectiva, a pesquisadora Grácia Maria Navarro, recupera o pensamento filosófico de Luigi Pareyson nas artes da cena em suas direções teatrais, para fazer surgir o formato de suas peças e sobre o que é esse formar, a citação que ela traz em sua tese acerca da Teoria da Formatividade de Pareyson nos esclarece que

\begin{abstract}
Em síntese, formar significa por um lado fazer, executar, levar a termo, produzir, realizar e, por outro lado, encontrar o modo de fazer, inventar, descobrir, figurar, saber fazer; de tal maneira que invenção e produção caminham passo a passo, e só no operar se encontrem as regras da realização e a execução seja a aplicação da regra no próprio ato que é a sua descoberta. (PAREYSON, apud NAVARRO, 2009, p33-34)
\end{abstract}

Amparar a criação artística na Teoria da Formatividade significa criar um jeito de fazer, que respeita às exigências poéticas que surgirem na criação dessa obra. Estar aberto ao processo criativo, mesmo que a criação parta de uma margem, nesse caso delimitada pelo conto e pela personagem em questão, é situar-se num lugar de risco, mas também de abertura à experiência.

A construção dessa personagem vem se apresentando como latência e desejo. Percebo 


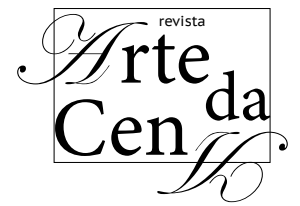

como necessidade suscitada pelo conto um trabalho processual, uma escuta ativa e criativa do processo. Na latência do que pode vir a ser pressinto a necessidade de criação de qualidades de movimento, de estado de fluxo, numa estética que se aproxima do ritual, no que diz respeito a criar sensações, através de sons, ruídos, cheiros, cânticos, texturas, imagens e dessa forma, possibilitar ao espectador por meio da fruição do espetáculo, participar da experiência cênica. A maneira como esses materiais irão traçar o enredo, dependerá da poética que a obra for suscitando. As reflexões, só se tornam possíveis na medida em que o processo gera espaços para a produção de conhecimento, neste caso em especial a teoria é indissociável da prática.

\section{Relato da experiência em processo de construção da personagem Lua Cambará.}

O conto Lua Cambará vem permeando meu imaginário, trazendo à tona visagens de outros mundos. Sentia que ele rondava à espera de se materializar na cena. Tamanha insistência acabou por instigar minha escolha em investigar a partir do conto, caminhos de composição artística onde questões ligadas à representação do feminino e matrizes da cultura popular brasileira se entrelaçam. Explorar qualidades de energia e presença, nessa experiência de criação de personagem me parece uma interessante, porém desafiadora, oportunidade para uma construção poética da cena.

Nesse tópico do trabalho, compartilho pistas a partir de três exercícios: laboratório, oficina e passeio, trazendo algumas considerações desse pontapé inicial, que trouxeram contribuições significativas para pensar os materiais metodológicos para a composição da personagem.

Na disciplina Laboratório de Criação, oferecida no segundo semestre de 2015, no programa de Pós Graduação em Artes da Cena na Unicamp, tive a oportunidade de desenvolver um primeiro exercício de construção da personagem Lua Cambará. Para tanto contei com o auxílio dos colegas da disciplina para serem os intérpretes. Nesse laboratório pedi aos colaboradores que se ajuntassem em três grupos e entreguei trechos do conto, os quais organizei conforme identificados o arquétipo de Yansã, Oxum e Nanã. Juntamente com os trechos entreguei imagens relacionadas a esses arquétipos e pedi que os grupos se colocassem permeáveis aos estímulos, e a partir desses estímulos, compusessem uma cena de breve duração.

Naquele momento, procurei investigar se seria possível usar fotografias, pinturas, imagens de esculturas que representassem os arquétipos de Yansã, Oxum e Nanã, como ignição criativa. 


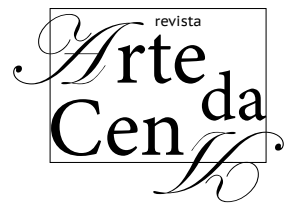

Dei algumas indicações de movimento e de vetores no espaço os quais relaciono com as danças desses orixás, mas em nenhum momento falei sobre arquétipos ou sobre essas danças, ou transmiti algum passo das mesmas. Queria ver o que os colegas fariam com esses materiais, o quanto poderia diferenciar do que eu havia concebido a priori para a execução de cenas surgidas a partir daqueles trechos do conto.

Os três grupos receberam cada um, um trecho do conto, fizeram suas escolhas e apresentaram as cenas. Os trechos foram os seguintes para a face guerreira/Yansã de Lua Cambará:

Juntou um "exército louco e mestiço, zumbis sem medo, arrastados por uma força de mulher.” (BRITO, 2003, p.151) "Calçava perneira, vestia gibão e montava cavalo feito homem. Mas a fêmea escapava de dentro de todas as amarras do couro". (BRITO, 2003, p.153). "Interpôs com o seu chicote, mulher avultada entre machos. (...) Queimou a palma da mão aberta como quem pronuncia uma sentença" (BRITO, 2003, p.157).

No primeiro grupo, percebi no instante da apresentação que havia apenas uma mulher e três homens, isso polarizou a cena de modo muito interessante. Os rapazes do grupo fizeram sons guturais, rugidos, grunhidos, em contraponto à voz suave e aguda da atriz que fazia vocalizes, aliados aos seus gestos imprimiam domínio e autoridade à cena. Como no exercício do platô ${ }^{2}$ eles evitavam permanecer todos no mesmo plano, a presença feminina tinha o mesmo peso e força na cena que a dos três rapazes equilibrando a cena numa tensão diagonal no espaço, em que o ponto de encontro gerou uma disparada, na qual os rapazes saíram antropomorfizados em cachorros feridos. Depois dessa experimentação, dei-me conta de que Lua Cambará podia cantar, vieram cantos diversos que tenho experimentado nos laboratórios individuais como, por exemplo, os Cantos da Lua, de Cristina Tati ${ }^{3}$.
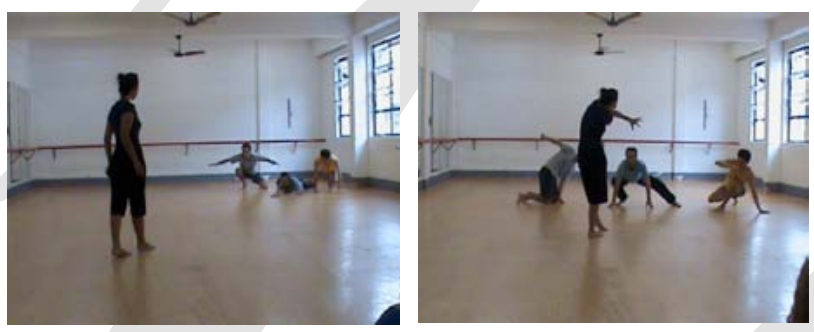

FOTOGRAFIAS 1 e 2. Apresentação da cena 1. Colegas da disciplina Laboratório de Criação: Arami Marchner, Marcelo Pessoa, Eduardo C. de Souza, Geraldo Rodrigues, laboratório de criação Lua Cambará em 11/11/15, investigação do arquétipo de Yansã em Lua Cambará, sala AD04, barracão das artes, Barão Geraldo, Campinas-SP, $2^{\circ}$ semestre de 2015.

Para a moça/Oxum: "Ela cresceu viçosa, nunca existiu mulher mais bonita! (...) Tinha um ciclo lunar e variava a cada lua”. (BRITO, 2003, p.147).

O segundo grupo, preferiu usar o ambiente 


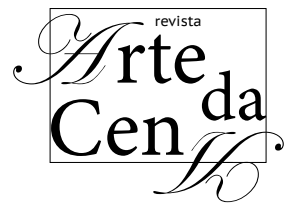

ao redor da sala de aula, realizando uma performance de interação com o espaço. Aproveitando para dar sentido às falas que elas inseriram apoiadas nos dados do texto, ora apenas murmurando, sussurrando, ora em tom audível e claro. Aqui o exercício apontou para a possibilidade de utilização cênica de lugares cotidianos, numa poética de criação com o espaço. Algo que ainda não tinha me ocorrido até o momento. Nesse grupo houve uma unidade, pareciam irmãs-feiticeiras a realizarem algum ritual de limpeza, de modo muito cúmplice e próximo, elas findaram a cena criando uma espécie de escultura em que uma se destacava das demais, como a representar essa tríade que é uma.
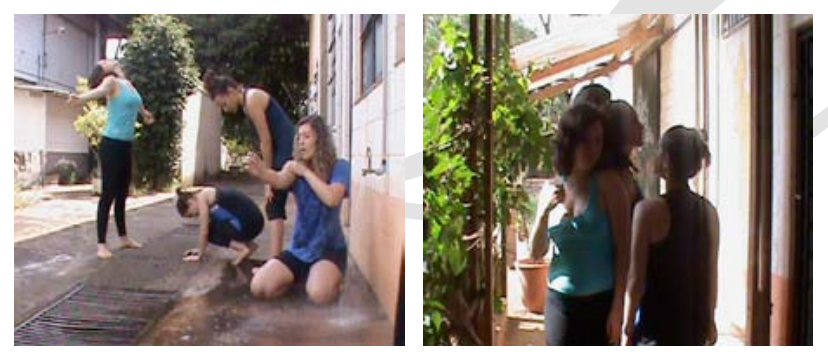

FOTOGRAFIAS 3 e 4. Apresentação da cena 2. Colegas da disciplina Laboratório de Criação: Renata Volpato, Bruna Campanhari, Bruna Munhoz, Bruna Reis, laboratório de criação Lua Cambará em 11/11/2015, investigação do arquétipo de Oxum em Lua Cambará, corredores das salas de dança do barracão das artes, Barão Geraldo, Campinas-SP, $2^{\circ}$ semestre de 2015.

O terceiro grupo recebeu esse trecho para trabalhar a face obscura, anciã/Nanã:

"Eram os três dias em que a lua morre. O vento da noite já soprava com força”. (BRITO, 2003, p. 142) (..) Uma desgraça estava pra acontecer" (BRITO, 2003, p. 156). "No corpo arruinado pelo sofrimento havia uma estranha magia, que provocava medo e entrega" (BRITO, 2003, p. 161-62). "Lua arrancou da garganta o grito que era da mãe, extraído de suas entranhas." (BRITO, 2003, p.165).
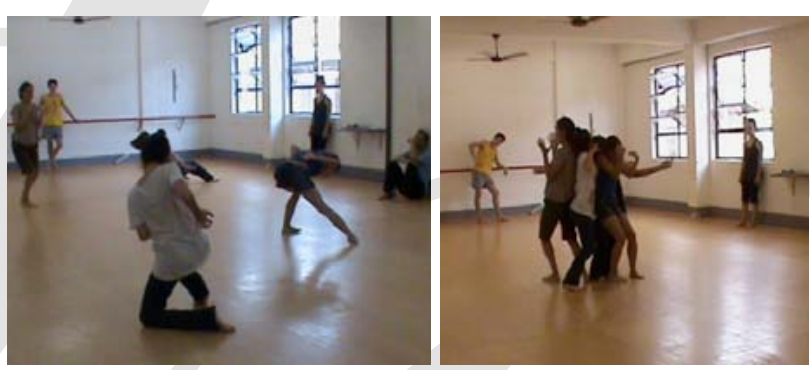

FOTOGRAFIAS 5 e 6 . Apresentação da cena 3. Colegas da disciplina Laboratório de Criação: Hariane Eva, Juliana Passos, Flávia Hiroki, Isabel Padovani. laboratório de criação Lua Cambará em $11 / 11 / 15$, investigação do arquétipo de Nanã em Lua Cambará, sala AD04, barracão das artes, Barão Geraldo, Campinas-SP, $2^{\circ}$ semestre de 2015.

$\mathrm{Na}$ apresentação desse grupo houve muitos movimentos de contorção, usaram a expressão do grito mudo. Improvisaram com a música Senhora Santana do coral de lavadeiras de Almenara, a qual finda com o verso "Que a faca que corta não dá tai sem dor", ou seja, a faca que não tem corte afiado é incapaz de tirar pedaço de qualquer coisa, a faca boa, corta, tira pedaço, mas pode causar também a dor. Para mim essa música sintetiza a sentença maldita de Lua Cambará. No trabalho desse grupo parecia que havia uma liga espessa e viscosa que unia as intérpretes, uma tensão das

Inácia Rita Maria Larissa Barros de Santana - Lua Cambará: um exercício poético de criação cênica. Arte da Cena, Goiânia, v. 3, n. 1, p. 108-127, Jan-jun/2017, 
bordas para o centro.

Encontros com outros artistas criadores pareceram-me coerentes visando à composição de uma personagem do imaginário popular. Esse laboratório deixou-me surpresa com os significados que os estímulos puderam assumir em outros corpos, pois tomaram formatos que eu não imaginava e que se revelaram tão ricos e de acordo com a proposta.

Essa ação despontou como centelha criativa e provocativa para levantamento de vocabulários corporais e desconstrução de padrões de movimento, dos caminhos já conhecidos, aos quais me vejo percorrendo quando inicio uma improvisação.

Uso as imagens aqui registradas num sentido de foto-grafias, no sentido de escritura poética semelhante às pinturas rupestres ou hieróglifos, cujos significados vão além da forma, como uma linguagem, dotada de signos e não somente como um recorte de uma partitura de movimento. Elas são fragmentos e registros da experiência, mas também momento de coleta de material para a pesquisa. Não poderei jamais reproduzir os movimentos exatos que os corpos dos colegas realizaram a partir dos estímulos oferecidos, porém, a partir do registro fotográfico ou audiovisual posso investigar a execução aproximada dessas partituras no meu corpo e ver quais conexões, sensações, impulsos, vão surgindo e de que maneira esse material pode se transformar.

A partir desse primeiro laboratório, um modo de fazer foi se apresentando para a abordagem do conto Lua Cambará e sua transposição para a cena. Percebi que ao lidar com o material em coletivo, outros pontos de vista puderam ser observados, outras perspectivas de cena, essa colaboração foi valiosíssima para desconstruir imagens prévias de como seriam as cenas a partir dos trechos selecionados. Outros modos de compor partituras vocais e sonoras puderam ser experimentados, diferentes daqueles que imaginava. Esse material alimenta a desconstrução das minhas criações prévias, me desestabiliza, me tira do conforto, me faz olhar para o conto com olhos diferentes. As cenas criadas pelos colegas podem ser um estímulo criativo de investigação, ao retornar a sala de ensaio. Outro palpite surgido por meio dessa experiência, além de abordar laboratórios com grupos de artistas, foi a utilização de espaços alternativos, espaços não teatrais a princípio, e assim lidar com a teatralidade de espaços cotidianos.

Delimitei a partir dessa experiência laboratórios de criação coletivos, em que eu direciono, observo, registro, laboratórios individuais, em que munida e avivada pelo coletivo, torno ao material 
aberta para investigar as partituras e descobrir estímulos vindos a partir delas, laboratórios coletivos em espaços cotidianos e laboratórios na sala de ensaio, de modo a criar numa via de mão dupla entre coletivo e a singularidade, os espaços abertos e sala de ensaio, entre a presença real e fotografada/filmada. Espero com esses laboratórios fortificados pelo coletivo, mas altamente singulares, adquirir repertório, desabituando o olhar que dirijo ao conto.

Após esse laboratório de criação, parti para a realização de uma oficina, agora com mais tempo para investigar cada trecho que selecionei do conto. Facilitei uma oficina de 21 a 23 de setembro de 2016 no Festival de Artes do Instituto de Artes, na Universidade Estadual de Campinas. Naquela ocasião, propus continuar investigando o arquétipo tríplice em Lua Cambará. Repeti alguns dos materiais da primeira oficina, como por exemplo, os trechos dos contos e as imagens. Mas desta vez procurei fazer com que a identificação com os arquétipos se desse de forma mais orgânica. Havia muitas alunas do curso de dança, elas esperavam que eu lhes ensinasse a dança de Oxum, Yansã e Nanã, e embora tenhamos passado por elas, esse não era o objetivo, mas que ao trabalhar os apoios do pé no chão, o arco da coluna, a continuidade de movimento, pudesse criar sensações corporais relacionadas às mudanças de equilíbrio, apoio e fluência.
A cada dia trabalhávamos um arquétipo, começamos com a moça/Oxum, depois com a guerreira/Yansã e finalmente a anciã/Nanã. A oficina tinha uma proposta de ser um espaço ritual de encontro com esses arquétipos a partir do conto Lua Cambará. Iniciávamos em roda, com o olhar, o silêncio e cantos que fui trazendo de acordo com cada arquétipo da personagem. No entremeio, havia um momento em que eu apresentava um breve passo da dança do Orixá relacionado ao aspecto da personagem trabalhado aquele dia. Ao final havia um espaço para que cada um improvisasse e apresentasse uma célula de movimento baseada no trecho do conto e no arquétipo trabalhado. Terminávamos também em roda, com um canto e olhar, até que ficássemos em silêncio novamente.

No entanto, ao introduzir o elemento do passo, a organicidade se perdeu. Havia uma tendência a imitar o que eu tinha feito, mesmo que eu insistisse que cada corpo podia sentir o caminho, a lógica daqueles elementos de um jeito diferente. Isso a meu ver limitou o trabalho, percebi algumas falhas na minha condução.

Embora assistir as cenas foi uma experiência de fruição estética dos corpos e sentisse que cada um fazia o seu melhor, o que de mais bonito o seu corpo poderia fazer com aquilo, eu mais apreciei do que achei algo que fosse possível de 
realizar no meu corpo e que fizesse sentido para $\operatorname{mim}$.

Houve dificuldades por parte do grupo em soltar a voz, mesmo produzindo sons, a grande maioria das cenas, eram mudas, nos dois primeiros dias. No entanto, no último dia, apresentei alguns materiais diferentes da primeira oficina para trabalharmos o aspecto da anciã em Lua Cambará.

Apresentei fotografias de mulheres idosas além daquelas relacionadas ao arquétipo de Nanã e li em voz alta um poema de Patativa do Assaré, chamado Mãe Preta. Quando terminei, algo aconteceu, havia uma moça aos prantos, outras com lágrimas nos olhos. O que poderia ter causado aquilo? Seria o próprio poema? Ou ela tinha acessado algum conteúdo pessoal? Sei que esse choro persistiu durante um tempo. Como eu havia pedido aos participantes que trouxessem um objeto que fosse importante, justamente essa moça havia trazido uma manta, na qual ela se enrolou em posição fetal até que por fim o choro cessasse. O trabalho continuou tendo ao fundo os seus soluços como sonoplastia. Pedi que as pessoas se ajuntassem em três grupos e trabalhassem a partir do trecho que narra a morte de Lua Cambará e que aproveitassem ou não das imagens, cantos e dança de Nanã.
Esse foi o momento mais interessante desses três dias. As cenas tiveram sons, canções, corpo. Fiquei profundamente agradecida com o que vi e resolvi filmar essas improvisações. Algumas imagens interessantes surgiram das composições. A meu ver elas remetem ao aspecto tríplice da personagem Lua Cambará, mas também mitologias do feminino simples, antigas. Como por exemplo, uma dessas improvisações terminava com uma fileira de três mulheres, uma em pé, outra de cócoras, uma no colo deitada ao chão e o único que rapaz que permaneceu até o fim, com o corpo curvado sobre a cena, parecia um velho a observar ou abençoar aquele nascimento. Eles faziam um trajeto diagonal em grupo como um corpo só, cantando trechos de canções, até terminar nessa imagem, com o canto se transformando pouco a pouco em sussurro. Um silêncio ficou no ar. Havia alguma ação ali, no tempo e no espaço.

Percebi nesse último dia, que trabalhar em parceria de trocas sobre esse material, seria pelo menos por ora, mais rico para o processo artístico. A personagem Lua Cambará carece de carne, uma carne múltipla, coletiva. Ao final de tudo, talvez seja difícil dizer que eu tenha criado a personagem, desconsiderando contribuições tão valiosas, quem sabe possa afirmar que esta criação se dê num plano do "nós".

No dia 18 de outubro de 2016, por volta

Inácia Rita Maria Larissa Barros de Santana - Lua Cambará: um exercício poético de criação cênica. 


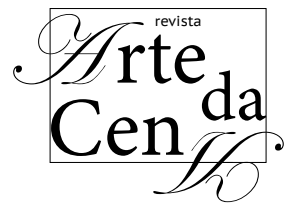

das $18 \mathrm{~h}$, na lua cheia, a convite entusiasmado de alguns pesquisadores do grupo de Pesquisa Pindorama 4 e juntamente ao grupo, fizemos um passeio na Praça da Paz na Unicamp, a fim de investigar a imagem primeira do conto Lua Cambará, em que o cortejo de vultos passa a vagar carregando a morta na rede. Caminhamos aproximadamente três horas, num tempo muito lento, todos vestidos de branco, exceto algumas pessoas que viram a ação e resolveram participar na hora, caminhamos todo o tempo por caminhos de terra à espera da lua.

Havia me preparado para cantar algumas canções que vinham fazendo parte do imaginário do conto nesse trabalho, tais eram elas: Cantos da lua, de Cristina Tati, (em que trabalhei com duas canções de invocação da lua no Santo Daime, desta compositora), Carcará, conforme cantado por Sandra Belê e Senhora Santana, das lavadeiras de Almenara. A ação era muito simples, a de transportar o corpo da morta na rede, enquanto isso deixava atrás de nós um caminho de flores brancas. Quando escureceu acendemos velas. Ficaram os rastros de nossos passos na terra, as pétalas murchas no chão. Teria sido perfeito, se nesse dia, não tivesse feito frio, se as nuvens não tivessem encoberto a lua, se as velas pudessem ficar acessas. Não houve outra mulher no cortejo. Cantar num espaço aberto tremendo de frio foi muito difícil. Mas apesar disso, comecei a entender porque quando penso na personagem, canções vem habitar, desejando ser cantadas. No desespero de poder ver a lua e cumprir o roteiro da ação, que era cantar assim que a lua se mostrasse no horizonte, acender as velas e partir deixando os rastros no espaço, pois do contrário, ela não teria fim. A sensação foi essa ao ver tantas nuvens no céu, perdi a noção do tempo, tive a sensação que nunca teria fim, decidi cantar mesmo sem saber se já havia lua no céu, ao cantar o desespero foi dando lugar à vontade de aconchego, o aconchego de um cobertor quente, um chá, uma sopa, um abraço quente. Então surgiu uma pista, Lua Cambará canta, já que a terra, o céu e inferno não podem lhe aceitar, ela canta para a lua, para se embalar, para buscar conforto ao seu destino de alma penada.
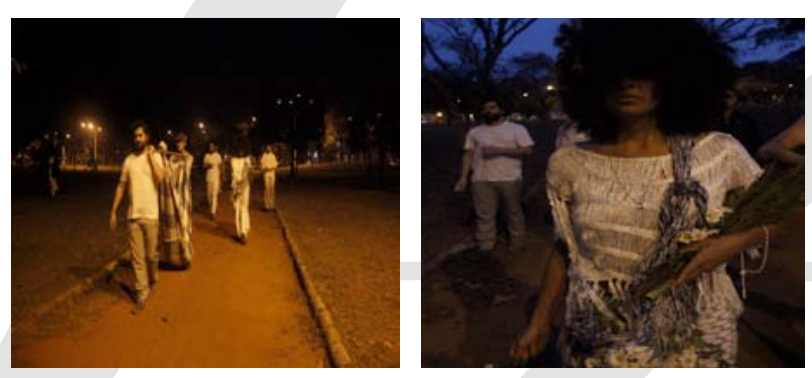

FOTOGRAFIAS 7 e 8. Colegas integrantes do grupo de pesquisa Pindorama: Alessandro Oliveira, Eduardo Cecconello, Ysmaille Ferreira, Inácio Azevedo e participantes Lauro Mota, Hugo Kojimiura e Victor Santos. Passeio, 18 de outubro de 2016.

Neste artigo, falei/escrevi sobre o conto Lua Cambará de Ronaldo Correia Brito, em que propus brevemente embarcar na sua escritura mítica. Defini Lua Cambará como uma personagem 
tríplice que apresenta as qualidades da moça, da guerreira e da anciã, o que me levou a uma relação entre a personagem central, Lua Cambará e os arquétipos de Oxum, Yansã e Nanã, verificando semelhanças entre as facetas da personagem e os mitos de Oxum, Yansã e Nanã em Reginaldo Prandi. Trouxe como norte metodológico para a criação e pesquisa em artes da cena, a percepção do processo criativo como gerador de conhecimento, na medida em que a obra demanda interesses e relações com outros campos do saber. Tracei como ponto de suporte metodológico para a criação, a Teoria da Formatividade de Luigi Pareyson, devido a sua aplicabilidade coerente a processos criativos de composição de obras artísticas. Relatei parte de uma experiência em processo, a partir de experimentações iniciais de criação e procurei compreender como a obra começou a se delinear.

Finalizo com um trecho do diário de bordo do dia 22 de fevereiro de 2017, em que de tanto penar sobre essa personagem acabei sonhando. Desse encontro resultaram o esboço escrito de algumas ideias para a criação de cenas:

Lua parece coisa viva que fala comigo através dos sonhos. Como pode uma personagem que eu ainda nem criei querer tomar o lugar da criadora? E eu o que faço, sou eu a criatura? Sou eu a personagem? Ela ainda não tem forma pode ser tudo, e como é fantasma, assombração, pode ter qualquer forma, muitos são os caminhos. O subconsciente não descansa, ele continua trabalhando. (...) Lua tem hora que parece que tem corpo de carne, tem ora que eu acho mesmo que é uma assombração...

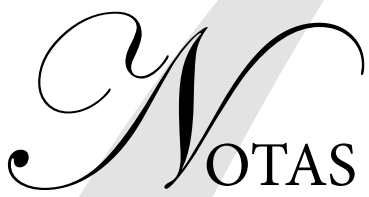

Faca-face de um feminino sertanejo: impressões do regionalismo contemporâneo em Ronaldo Correia Brito.

2 Esse é um exercício realizado em alguns treinamentos de ator, em que os atores se posicionam na sala e imaginando que esta é uma bandeja suspensa no ar, equilibra-se as presenças no espaço, como se fossem objetos na bandeja, o propósito é não deixar que a cena pese mais para um lado mas que haja espaço entre os corpos suficiente para que a bandeja não despenque. Pode-se ir acrescentando dificuldades. Nessa ocasião, houve um equilíbrio interessante, pois havia um grupo formado por uma única atriz e outro formado por três atores, a tendência esperada é que a cena pendesse para o lado que havia mais pessoas, mas isso não aconteceu.

3 Ao final do trabalho trago um tópico com as referências poéticas dessas experimentações caso, o leitor tenha interesse em ouvir.

Inácia Rita Maria Larissa Barros de Santana - Lua Cambará: um exercício poético de criação cênica. Arte da Cena, Goiânia, v. 3, n. 1, p. 108-127, Jan-jun/2017, 
O grupo nasceu e faz parte da Universidade Estadual de Campinas desde 2010. É formado por pesquisadoras e pesquisadores do teatro, da dança e da performance, vinculados ou oriundos de pesquisas de iniciação científica, mestrado e doutorado dos Programas de Graduação e PósGraduação em Artes da Cena da UNICAMP. O escopo de pesquisas do grupo vai desde a espetacularidade popular brasileira, à produção teatral na contemporaneidade. O Pindorama tem se tornado um grupo cada vez mais afeito aos diálogos entre linguagens artísticas tendo flertado com o cinema, a música e as artes visuais performativas.

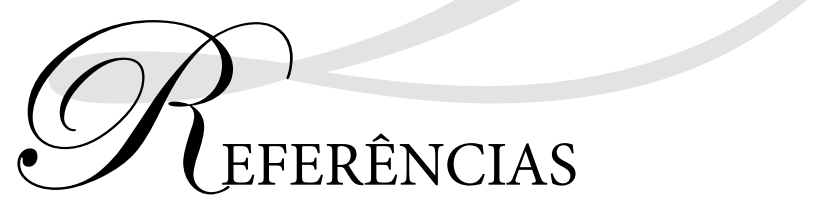

BOLOGNESI, Mario Fernando. Experiência e história na pesquisa em artes. Art Research Journal/ Revista de Pesquisa em Arte. ABRACE, ANPPOM em parceria com a UFRN. Rio de Janeiro: 2014. 119p. vol. 1/1, ISSN: 2357-9978. 2014. 119p. Disponível em:

https://periodicos.ufrn.br/artresearchjournal/ article/view/5258 acessado em 11 de ago. 2016.

BRITO, Ronaldo Correia. Lua Cambará. IN: BRITO, Ronaldo Correia. Faca. São Paulo: Cosac \& Naify . 2003. 184p. ISBN: 85.7503- 174-0.
CLARK, Nathália Perry. Faca-face de um feminino sertanejo_impressões do regionalismo contemporâneo de Ronaldo Correia Brito. Brasília: Programa de Pós-Graduação em Literatura/Universidade de Brasília. 2011. Dissertação (mestrado em Literatura e outras áreas do conhecimento).

CZIKSZENTMIHALY, Mihaly. A descoberta do fluxo: a psicologia do envolvimento com a vida cotidiana. Tradução de Pedro Ribeiro. Rio de Janeiro, Editora Rocco, 1999. ISBN 85.325.1014-0.

ELIADE, Mircea. Mitos, Sonhos e Mistérios. (Mythes, Rêves et Mystères, tradução de Samuel Soares) Lisboa, Portugual: Editora Edições 70, 1989.

FABIÃO, Eleonora. Corpo Cênico, Estado Cênico. Revista Contrapontos. Rio de Janeiro: 2010. 321-326p. vol.10, n.3. Disponível em: http:// siaiap32.univali.br/seer/index.php/rc/article/ viewFile/2256/1721 Acessado 31 de jul. 2016.

JACOBI, Jolande. Complexo, arquétipo, símbolo na psicologia de C. J. Jung. São Paulo: Editora Cultrix, 1995.

NAPOLI, Franceso. Luigi Pareyson e a estética da formatividade: um estudo de sua aplicabilidade da poética do read-mady. Ouro Preto: Programa de Pós-Graduação em Filosofia, Artes e Cultura/ Universidade Federal de Ouro Preto. 2008. Dissertação. (Mestrado em Filosofia).

NAVARRO, Grácia, Maria. Corpo Ficcional: da Dança Brasileira ao Teatro Contemporâneo. Campinas: Programa de Pós-Graduação em Artes da Cena/Universidade Estadual de Campinas. 2009. Tese. (Doutorado em Artes).

PRANDI, Reginaldo. Mitologia dos Orixás. São Paul: Editora Companhia das Letras, 2001. 591p. ISBN: 978 - 85 - 359 - 0064 - 4.

ROYO, Victória Pérez. Sobre a pesquisa em artes: um discurso amoroso. Revista Brasileira 
de Estudos da Presença. Porto Alegre: 2015. 533 558p vol.5, n³. E-ISSN; 2237-2660. Disponível em: http://www.seer.ufrgs.br/presen\%C3\%A7a acessado em 11 de ago. 2016.

REFERÊNCIAS POÉTICAS (na ordem que foram citados).

Cristina Tati, Cantos da lua: cd Hinos do Santo Daime. Músicas Oh lua (00:00) e Lua cheia (01:57).

Lavadeiras de Almenara, Senhora Santana. Disponível em: https://www.youtube.com/ watch? $\mathrm{v}=\mathrm{oHKAAt} \mathrm{j}$ DmE Acesso em 30 de mar. 2017.

Patativa do Assaré. Mãe Preta. (Poema e voz de Patativa do Assaré). Disponível em: https://www. youtube.com/watch?v=FT0bf8tN9aw Acesso em 30 de mar.2017.

Sandra Belê, Carcará. (Interpretação de Sandra Belê acompanhada pelo violonista Zeferino). Disponível em:

https://www.youtube.com/watch?v=Lm-kmnmI-5k Acesso em 30 de mar.2017.
* INÁCIA RITA MARIA LARISSA BARROS DE SANTANA é Mestranda no Programa de PósGraduação em Artes da cena, na Universidade Estadual de Campinas. Graduada no curso de Bacharelado em Teatro pela Universidade Federal da Paraíba (2014). Graduada em Letras pela Faculdade de Formação de Professores de Afogados da Ingazeira (2009), com habilitação em português e inglês. É atriz profissional, dançarina, poetiza, brincante e pesquisadora da cultura popular brasileira.

Artigo submetido em: 30/03/2017

Aprovado em: 19/06/2017

Inácia Rita Maria Larissa Barros de Santana - Lua Cambará: um exercício poético de criação cênica. 